2009

\title{
Intellectual Property Rights and the Right to Participate in Cultural Life
}

Molly Beutz Land

New York Law School

Follow this and additional works at: http:// digitalcommons.nyls.edu/ innovation_center_for_law_and_technology

\section{Recommended Citation}

Land, Molly Beutz, "Intellectual Property Rights and the Right to Participate in Cultural Life" (2009). Innovation Center for Law and Technology. Book 1 .

http://digitalcommons.nyls.edu/innovation_center_for_law_and_technology/1 


\section{㽞雷 \\ Institute for \\ INFORMATION \\ LAW \& POLICY \\ at New York Law School}

Institute for Information Law and Policy

White Paper Series 08/09 \#02

\section{Intellectual Property Rights and the Right to Participate in Cultural Life}

Molly Beutz Land

Associate Professor, New York Law School

(http://www.nyls.edu/faculty/faculty_profiles/molly_k_beutz)

Background paper submitted to the Committee on Economic, Social, and Cultural Rights (revised November 2008 for public distribution)

New York Law School's website can be accessed at www.nyls.edu 


\title{
Intellectual Property Rights and the Right to Participate in Cultural Life
}

\author{
Background paper submitted by Molly Beutz Land ${ }^{1}$
}

\begin{abstract}
$\underline{\text { Abstract }^{2}}$
Although many contend that human rights law is a justification for intellectual property rights, precisely the opposite is true. Human rights law is far more a limit on intellectual property rights than a rationale for such regimes. In a variety of ways, human rights law requires states to take specific, concrete steps to limit the effects of intellectual property rights in order to protect international human rights. This powerful and emancipatory dimension of human rights law has unfortunately been overshadowed by those who claim human rights as a basis for granting exclusive rights.

The U.N. Committee on Economic, Social, and Cultural Rights - the body created to monitor state compliance with the terms of an international treaty called the International Covenant on Economic, Social, and Cultural Rights - is in the process of drafting a General Comment that will interpret the "right to take part in cultural life," a right protected under Article 15(1)(a) of the treaty. The submission that follows was designed to provide the Committee with an overview of some of the ways in which intellectual property rights can affect this right and what states may be required to do to protect the ability of individuals to participate in cultural life.
\end{abstract}

\section{Introduction}

The purpose of this submission is to describe several ways in which intellectual property rights can affect the right to participate in cultural life. In its General Comment No. 17, the Committee emphasized that states are obligated to seek an appropriate balance between measures to protect authors' moral and material interests, which may include the grant of exclusive rights, and rights such as the right to take part in cultural life. ${ }^{3} \mathrm{~A}$ new General Comment interpreting Article 15(1)(a) of the Covenant provides a valuable opportunity to articulate measures states may implement to achieve this balance.

\footnotetext{
${ }^{1}$ Associate Professor of Law, New York Law School. The author wishes to acknowledge the excellent research and translation contributions of Stephanie Figueroa, Jillian Howell, and Nicole Kennedy.

${ }^{2}$ This abstract was added after submission to the Committee.

${ }^{3}$ General Comment No. 17, The right of everyone to benefit from the protection of the moral and material interests resulting from any scientific, literary or artistic production of which he or she is the author (article 15, paragraph 1 (c), of the Covenant), U.N. Doc. E/C.12/GC/17, 12 January 2006, ๆ 39(e).
} 
This submission does not seek to reiterate arguments raised in connection with the drafting of General Comment No. 17. Instead, its goal is to describe, based on wellestablished principles articulated by the Committee in its jurisprudence, several ways in which states may need to limit domestic intellectual property rights in order to adequately protect the right to participate in cultural life. This is an issue that the Committee has identified as a concern in its General Comment No. 17 and one to which it is uniquely positioned to respond.

\section{Participatory and Protective Dimensions}

Domestic intellectual property rights can affect both the ability to participate in cultural life as well as the very essence of people's culture. As Yvonne Donders has argued, the meaning of cultural life "now represents, in accordance with the anthropological approach, a way of life of individuals and communities." Individuals require access to cultural goods in order to be able to participate in and create meaning in connection with these ways of life. In this sense, the ability "take part" in cultural life requires that individuals be able to consume, transform, and share culture.

At the same time, however, individuals and communities also need control over and protection of their cultural goods from access by others in order to preserve their way of life. The right to "take part" in cultural life thus also requires that individuals and communities have the ability to set the conditions under which cultural goods associated with their ways of life are consumed, transformed, and shared. ${ }^{5}$

Intellectual property rights can affect both the participatory and protective dimensions of the right to participate in cultural life. This submission will address only the participatory dimension - that is, how intellectual property rights can affect the ability of individuals to consume, transform, and share culture.

\section{Participation in Cultural Life}

Intellectual property rights can restrict the ability of individuals to participate in cultural life by limiting their access to cultural goods. ${ }^{6}$ The ability to participate in a particular

\footnotetext{
${ }^{4}$ Yvonne Donders, Cultural Life in the Context of Human Rights, U.N. Doc. E/C.12/40/13, 9 May 2008, p. 7; see also Elsa Stamatopoulou, Cultural Rights in International LaW: Article 27 OF the Universal DECLARATION OF HUMAN RIGHTS AND BEYOND 109 (2007).

${ }^{5}$ See Rosemary Coombe, Cultural Rights and Intellectual Property Debates, Human Rights Dialogue: "Cultural Rights," 2(12), pp. 34-36 (Carnegie Council on Ethics and International Affairs, Spring 2005).

${ }^{6}$ Consistent with the broad understanding of "cultural life" reflected in the Committee's jurisprudence, see Donders, supra note 4, p. 7, cultural goods would include not only art, literature, and music, but also clothing, shelter, folk arts, crafts, television, radio, sports, and movies, among many other types of goods that are created as part of or which in other ways reflect an individual or community's way of life. The broad
} 
way of life depends on being able to access the cultural goods that define that way of life. When individuals are prevented from accessing cultural goods, or when the amount or diversity of cultural goods they can access is unreasonably limited, they are hampered in their ability to use, transform, and share culture. As such, access to cultural goods can be viewed as an underlying determinant of the right to participate in cultural life. ${ }^{7}$

The participatory dimension of the right to take part in cultural life also requires the ability to share and transform culture. Individuals "take part" in cultural life as both consumers and creators of culture. Because cultural life is a product of interactions within a community, the right to participate in cultural life necessarily includes being able to share cultural goods with others. ${ }^{8}$ Transformative use is also central to this right. Culture does not exist in a vacuum but rather develops and evolves as it is shared and transformed, and creating cultural works often involves building on and transforming existing cultural material. Sharing and transformation are thus integral parts of what it means to "take part" in cultural life and are necessary to meaningfully realize this right.

Finally, limitations on access to cultural goods also have significant implications for the ability to participate in the cultural life of one's choosing. Intellectual property laws can impair the overall quantity and diversity of the cultural goods in the public domain. Diversity of cultural goods helps to ensure that individuals are able to choose the cultural life in which they participate. ${ }^{9}$ Incremental restrictions on cultural goods thus limit the absolute amount of materials available to individuals as well as their ability to choose which materials to access.

\section{Limits on Participation}

There are several ways in which intellectual property laws can limit the right to take part in cultural life. First, exclusive rights can limit access to cultural goods. Cultural goods under copyright might be unavailable if the copyright owners decide not to disseminate particular works. Copyright can also contribute to a lack of translations of works in less widely-spoken languages, if copyright owners do not create such translations or allow

\footnotetext{
democratization represented by the anthropological understanding of cultural life is thus accompanied by a corresponding increase in the quantity and diversity of what we might understand as cultural goods.

${ }^{7}$ Those aspects of a right that are necessary for the right to be meaningfully realized must be protected together with the right itself. See General Comment No. 14, The right to the highest attainable standard of health, U.N. Doc. E/C.12/200o/4, 11 August 2000, ๆ 11. Access to the Internet might be another underlying determinant of the right to participate in cultural life.

${ }^{8}$ The right to participate in cultural life has "collective dimensions" even if it is understood as an individual right. See Donders, supra note 4, p. 5.

${ }^{9}$ See, e.g., id. p. 4 (noting that the Committee's Revised Guidelines foresee a role for cultural communities other than the national community); Julie Ringelheim, Integrating Cultural Concerns in the Interpretation of General Individual Rights - Lessons from the International Human Rights Case Law, U.N. Doc. E/C.12/40/4, 9 May 2008, pp. 6-7 (discussing the importance of cultural diversity).
} 
them to be created by others. ${ }^{10}$ Works may also be geographically inaccessible if publishers or authors decide not to allow their distribution in particular countries.

Further, access might be limited if authors take advantage of exclusive rights to charge prices that make the works unaffordable and thus effectively unavailable. For example, copyright allows publishers to charge prices for textbooks that may be difficult for many consumers to pay. ${ }^{11}$ Access to educational materials such as textbooks affects not only an individual's right to education, but also his or her ability to meaningfully take part in cultural life.

Access can also become prohibitively expensive if users are required to obtain multiple licenses in order to use a particular work. ${ }^{12}$ One commentator noted, for example, that the difficulty of navigating multiple sets of ownership rights and the threat of litigation was likely to discourage houses of worship in the United States from using copyrighted materials during services. ${ }^{13}$ The author explained that most houses of worship cannot afford the high cost of negotiating license fees or defending against copyright litigation and were likely to be deterred from using the artistic expressions of popular culture music, sketches, dramatic scenes, and videos - that have become an important element of contemporary worship services. ${ }^{14}$

Second, states have also implemented measures to protect intellectual property that have a significant impact on the ability of individuals to share and engage in transformative use. For example, some states have enacted laws that impose criminal or civil liability on acts that circumvent technological measures that limit the uses that individuals can make

${ }^{10}$ See Catherine Saez, Press Release, IP Rights Arise in UN Debate on the Right to Participate in Cultural Life, Intellectual Property Watch, 15 May 2008.

${ }^{11}$ See Eddan Katz, "The Right to Education Threatened by the IP Copyright Regime," presentation at panel, "Tackling the Negative Impacts of Intellectual Property Systems: A Human Rights Approach," 13 March 2008 (noting that publishers obtain returns of up to $200 \%$ on textbooks in specialized fields), available at http://www.3dthree.org/pdf_3D/3DHRIPPanel.pdf; see also Noam Cohen, Don't Buy That Textbook, Download It Free, N.Y. TIMES, 15 September 2008.

${ }^{12}$ See Michael Abramowicz, A Theory of Copyright's Derivative Right and Related Doctrines, 9o MiNN. L. REV. $317,384-85$ (2005) (noting that "it might be very expensive to contact the many copyright owners of each of the included works for permission and to change a work should permission not be granted").

${ }^{13}$ Brian D. Wassom, Unforced Rhythms of Grace: Freeing Houses of Worship from the Specter of Copyright Infringement Liability, 16 FORDHAM INTELL. PROP. MEDIA \& ENT. L.J. 61, 181-82 (2005).

${ }^{14}$ Id. Although this example is from the United States, which is not party to the Covenant, examples from states that have ratified the Covenant and from developing countries in particular are difficult to obtain, reflecting an urgent need for states to set benchmarks and monitor the way in which intellectual property rights are affecting the right to participate in cultural life. See General Comment No. 1, Reporting by States parties, U.N. Doc. E/1989/22, 24 February 1989, ๆ 3. Examples are also difficult to obtain because legal reforms that introduced stronger intellectual property rights in many countries were implemented only relatively recently. The Agreement on Trade-Related Aspects of Intellectual Property Rights, for example, allowed developing countries until January 1, 2000 to comply with its provisions. Agreement on TradeRelated Aspects of Intellectual Property Rights, Apr. 15, 1994, 1869 U.N.T.S. 299, 33 I.L.M. 1197, art. 65.2. Least-developed countries have until July 1, 2013 to comply. Council for TRIPS, Extension of the Transition Period under Article 66.1 for Least-Developed Country Members, IP/C/40, 29 November 2005. 
of particular cultural works. ${ }^{15}$ These laws may prohibit circumvention even when the purpose of the circumvention is to enable a lawful use. A teacher, for example, might circumvent technological protection measures in order to create video clips for class. Even if the use is protected under existing copyright law, the teacher may still be liable for the act of circumvention. Such provisions unreasonably restrict the right to participate in cultural life.

Although there are a variety of barriers that inhibit the dissemination of cultural goods, copyright as a barrier is likely to assume increasing importance in light of the ease with which digital content can be distributed via information and communication technologies. As the Office of the High Commissioner for Human Rights has observed, information and communication technologies can be used to, among other things, "advance cultural diversity and multilingualism through the creation and dissemination of local contents and cultures." ${ }^{16}$ Distance education programs, the widespread use of mobile phones, and access to the Internet all contribute to the increasing availability of cultural content. The overly restrictive enforcement of copyright in digital works thus poses the risk of undermining the potential of new technologies to contribute to the dissemination of cultural goods.

\section{Measures for Ensuring Participation}

There are several different types of measures states might rely on to address limitations imposed by intellectual property laws. Under appropriate conditions, states might use compulsory licensing to increase access to particular goods. States may also take steps in designing their intellectual property regimes to limit the scope and range of rights that are granted so as to protect a vibrant and diverse public domain. Finally, states may take measures to define copyright and impose exceptions and limitations on copyright rights in order to preserve the ability of individuals to consume, transform, and share cultural goods.

For example, domestic legal regimes may, and often do, exclude particular material from copyright protection - for example, by requiring that protected works meet the criteria of originality or extending protection only to the artist's expression and not the underlying idea. Intellectual property laws may also include exceptions and limitations to copyright, such as exceptions for speeches, education, reporting, parody, and quotations, among many others. Such exceptions and limitations can be critical in ensuring that individuals

\footnotetext{
${ }^{15}$ Anti-circumvention laws are required under the WIPO Copyright Treaty and have been implemented in the European Union, Japan, Australia, and the United States. See generally June M. Besek, AntiCircumvention Laws and Copyright: A Report from the Kernochan, 27 COLUM. J.L. \& ARTS 385 (2004). Anticircumvention provisions have also been included in free trade agreements the United States has entered into with countries such as Chile, Singapore, Australia, Morocco, Bahrain, El Salvador, Honduras, and Nicaragua. See generally Anupam Chander, Exporting DMCA Lockouts, 54 CLEVELAND STATE L.R. 11 (2006).

${ }^{16}$ High Commissioner for Human Rights, Background Note on the Information Society and Human Rights, U.N. Doc. WSIS/PC-2/CNTR/178-E, 27 October 2003, p. 4.
} 
have access to cultural works and that states achieve the balance recommended by the Committee in General Comment No. $17 .^{17}$

Clearly, the way in which this balance is worked out in national law will vary by country and issue. What may be an appropriate limitation in one geographic area or industry may not be appropriate in another. Although it may not be possible to specify how states should implement this balance, intellectual property laws should nonetheless avoid unreasonably restricting access to cultural goods. It is also important for states to implement and ensure the continued existence of provisions in their domestic intellectual property laws that allow consumers to use, transform, and share cultural goods. Examples might include compulsory licensing, limits on the scope of exclusive rights, and exceptions and limitations to copyright.

Finally, the adequate enforcement of such provisions, exceptions, and limitations is critical. Even states that allow compulsory licensing in their domestic law may be reluctant to rely on such a provision for fear of adverse reactions from other states. ${ }^{18}$ Concern about negative consequences associated with the use of flexibilities guaranteed under domestic law may prevent states from taking necessary steps to protect those within their jurisdiction. Further, failure to enforce exceptions under domestic law may have a chilling effect on individual consumers and creators. States should ensure that the exceptions and limitations to copyright enshrined in domestic law are effectively protected and available.

\section{Non-Retrogression}

Intellectual property rights continue to increase in strength under the domestic laws of many states around the world. Stronger copyright laws may be impermissibly retrogressive if they result in decreased protection of human rights. As the Committee has emphasized, the requirement of progressive realization means that states must "move as expeditiously and effectively as possible" toward the goal of full realization of the rights protected under the Covenant, and "any deliberately retrogressive measures in that regard would require the most careful consideration and would need to be fully justified

\footnotetext{
${ }^{17}$ For an extensive discussion of the way in which states might limit intellectual property rights in ways that protect creative freedom, see P. Bernt Hugenholtz \& Ruth L. Okediji, Conceiving an International Instrument on Limitations and Exceptions to Copyright, Final Report, pp. 11-16, 6 March 2008. As Hugenholtz \& Okediji explain, "appropriately designed L\&E's [limitations and exceptions] may alleviate the needs of people around the world who still lack access to books and other educational materials." Id. p. 11.

${ }^{18}$ In the context of patents, for example, the U.S. Trade Representative placed Thailand on its "Priority Watch List" after Thailand announced that it would issue compulsory licenses for two critical drugs. Kevin Outterson, Should Access to Medicines and TRIPs Flexibilities Be Limited to Specific Diseases?, 34 AM. J.L. \& MED. 279, 282 (2008).
} 
by reference to the totality of the rights provided for in the Covenant and in the context of the full use of the maximum available resources." ${ }^{19}$

Increases in intellectual property rights may be accompanied by decreases in the protections afforded the right to participate in cultural life, as fewer cultural goods enter the public domain or goods become less accessible. As a result, states contemplating measures to strengthen intellectual property rights in ways that restrict individuals' ability to take part in cultural life should give such measures the most careful consideration and justify them by reference to their existing obligations under the Covenant. For example, states contemplating the extension of copyright terms under domestic law would be required to demonstrate either that the extension will not unreasonably burden the right to take part in cultural life or that such burden is warranted in order to protect other rights under the Covenant.

\section{Conclusion}

The Committee has already emphasized the importance of protecting the underlying determinants of rights and strictly justifying retrogressive measures. In the context of intellectual property, these principles mean that states may be required to take steps to protect access to cultural goods and the ability to engage in transformative use, and to proceed carefully where domestic legal reforms would limit these capacities. Applying these principles to intellectual property would provide additional guidance to states about what is required to protect the right to take part in cultural life in the context of intellectual property and to balance the obligations enshrined in Article 15(1)(a) and (c) of the Covenant. ${ }^{19}$ General Comment No. 3, The nature of States parties obligations (Art. 2, par.1), U.N. Doc. E/1991/23, 14
December 1990, 9 . 